\title{
Romance of Village: A Way to Uncover the Story of Small Characters in War
}

\author{
Hongxia Zhang \\ Zhejiang Yuexiu University, Shaoxing 312000, Zhejiang Province, China
}

Fungding: This paper is the conclusion of the scientific research project (No. N2020005) in 2020 of Zhejiang Yuexiu University.

\begin{abstract}
The Village is a unique war story. It takes the life of ordinary little people to dig out the cruel corner of the war, and has the characteristics of the war theme works. However, it shows different aesthetic styles with unique artistic techniques by showing heaviness with lightness, and showing sadness with joy.
\end{abstract}

Keywords: War; Comedy; Survival; Ordinary people

Publication date: April, 2021; Publication online: 30 April, 2021

*Corresponding author: Hongxia Zhang, 125321688@qq.com

\section{Introduction}

The Village at the Geisel Theatre in Israel can either be seen with ease and pleasure, or with a wallow in pain, which shows how rich the connotation is. But it seems indescribable to explore its goodness. There is always this kind of excellent works that immerse in the hearts of the audience in the unconscious step by step.

In China, part of the rural dramas belong to the traditional opera stage. While on the stage of drama, prosperity and benchmark still stay in the 1980s and 1990s. Modern operas, as the main position of the current rural themes, are basically the main melody works. Even if the leading roles are no longer all village cadres, they must be higher grade little people. On behalf of the height of rural drama, The Record Event of Sang Shu Ping and Doggie's Nirvana are all about the pain and suffering, and there is no new perspective. Just as some exploration shows like to show the damage of war to people in a straightforward way, from the acclaimed Common Ground to the pioneering experiment Eyal Weiser How's the Beast, they directly tell the audience how the big political context can influence the little guys.

\section{Analysis of the story being unique from three perspectives}

Whether it's a war-like approach, or the more familiar realist depiction of a tragic historical drama about the war of resistance or its victims, it's all too common and makes you wonder if it's consumer politics. The Village rejection of grand narrative angles and its presentation of the beauty of life in the midst of war is striking.

\subsection{First, put the war in context}

Had it not been for the arrival of Sonia, a Holocaust survivor in the second half, the invasion of the war into the Village would have been almost comic, making us carelessly forget that this was the place where the fighting took place. But even when Sonia took her family's death with her to join her relatives, the play simply made them cry as they talked about it. And since then, she lived a normal life. She even began an affair in the fields, and it continued, as the war intensified in the second half - when the country was in greater danger - and she left happily with Earl, who had just said goodbye to the British Captain. Captain True and Earl's wife Clara's love, in the final farewell only with a voice-over to show a bit of sadness after the fleeting. The quarrel between two Italian prisoners of war over what Italy is, the performance and the lines were a little exaggerated spoof. Even the cruelty of the young boy, Amie, having to go to war was tempered by his flirting with his lover. Ami acknowledged his fear and brought us closer to the hero, who further interpreted his brave act as being for his lover. Once again, the audience laughed, knowing that young love is likely to have this kind of discretion.

The synopsis says that: "... Yossi is more concerned with the lives of his friends and family than with national issues, 
until others invade his world and destroy everything..." It is hard to avoid inferring that the second half follows a pattern: the front shows the good, the back destroys, and thus reveals the evil of war. However, the biggest satisfaction of the audience is surprise. If you can guess the beginning and miss the end, it is a good play.

\subsection{Secondly, put an end to ideological preaching and moral judgment}

Clay got on the British captain's motorcycle and drove off. Knowing that Yossi could not lie, she still asked Yossi to tell her husband that she had gone to look at the sheep. It was full of easy ridicule to her husband, and the people accepted this behavior against so-called social ethics gladly. Unbeknownst to all, further than the two people was her husband, grayhaired Dr. Eard, who was unable to resist a tryst with the fugitive Sonya in the field. The old doctor indulged in love, which had already made the audience feel that they could live freely and unfetted no matter how old they were. Sonia, who beared the bloody family misfortune, continued to live in this way, which made people feel liberated, released and happy.

Yossi's grandmother, on the other hand, was still trying to persuade Yossi's uncle to give poor Sonya a new life, to bring her out of the shadows. Yossi's Uncle responded calmly to the sight of the two, who were not so close together in the play, but who were still happy in the haystack on the stage. The comic effect of this arrangement was to dilute the young gloom of a very old, single uncle. It also showed a hint of sadness. As Hegel believes, "The opposing forces that constitute the conflict of tragedy are in the same position in the ethical sense, so the real tragedy is not the conflict between good and evil, but the conflict between good and good."(Ruxin, Yang Yu. Hegel's Tragedy Theory. 1962) People around Sonia were not imposing their will on her. As her uncle's expression, the plain language was full of tolerance and respect. Sonia had moved on, but it doesn't have to be a relative to take her in.

In our rural dramas, the fate of women is so tragic and even heroic. Women who remarry with their own family members following the custom live a miserable life, while women who struggle with death die a heroic death. They are always forced to lose their self-esteem by authoritative parents or members of powerful groups. The opposite of these women, the feudal parents who preside over the implementation of feudal atrocities, have to do it. Everyone is under the high moral code, or numb, or helpless, or nervous, or pain. It is a rare settlement, even they are not wrong from their own positions. "The fundamental tragedy here lies in the fact that the opposing parties in this conflict have their own justifications, and that the only thing each party can make the real content of the purpose and character to which it insists is to negate or destroy the other, which has the same justifications. Thus, both sides are upholding an ethical ideal and by fulfilling it they fall into sin."( Hegel. Aesthetics (Volume 3). Translated by Zhu Guangqian.1981)

In the small village where Yossi lives, each person can be happy in his own way. And this kind of happiness does not build on the pain of others. Sonia embodies a valuable sense of survival. In fact, this is the instinct of war themes to seek advantage and avoid harm. When bad things happen, we still have the desire to be happy. We see it too often that women whose families have been killed and get away with it will go mad. Men will be obsessed with revenge. How dare you talk about happiness when your life is ruined. Here we have to mention the specification again. "This nation is worthy of admiration. We need such a spirit, in the face of disaster, in the face of death, and in the face of all the suffering. Even if the fate is not easy, the victory will come." If victory is the only meaning, or the ultimate meaning, that sustains human life in the midst of constant disaster and death, then what about defeat? Is it right to encourage the people that victory will come, while the war is still raging, no matter how great their suffering is? From the perspective of The Village, the spirit of those people is not just the persistence of faith in the hope of victory, but the ability to live every day and every small day in front of us. Even if our favorite brother is killed in the battle, even if the whole family is killed, we still have the ability to be happy as time passes. Therefore, the important spirit is not to believe in the persistence after victory, but to be able to walk towards happiness in the suffering with indomitable strength even if we have no judgment on the war.

\subsection{Third, the "fool" without the omniscient perspective and the priest with the de-sublimation}

The fool is a favorite narrator in art, usually a prophetic being who prophesies and witnesses the historical changes of the protagonist or of a family, an institution or an era. Thus the fool is often the sight of God as all-knowing and omnipotent, or of being that is everywhere but still invisible to others. Yossi in The Village rarely ends up in other people's private spaces, where no one cares because he is so naive. Yossi opens with a narrative stance of omniscience, 
introducing himself with the word "fool". But as the story goes on, we find that he is not the kind of fool who needs the recipient to judge "ugly", he is more like a child who has not grown up. In particular, the scenes of Yossi and the goat, though slightly delayed, are intoxicated by the beautiful imagination of their childlike world in their pure love relationship. Like Yossi and the goat, they are reluctant to pull away. The villagers in the play never laughed at him and ignored him, but indulged him to care for him. As a result, he was not only a cold-eyed, silly spectator of other works of art, but a real participant in rural life. Based on this role positioning, he does not have the omnipotence perspective as other fools. The philosophical attributes conveyed by fools are also replaced by a strong smell of country life. The creators abandon the enlightenment and truly show the true nature of life.

Not only are fools treated more like ordinary people, but priests, who in other works are often the representatives of the respectable, or the enlighten of the chaotic masses, or the bearers of the heavy yoke of suffering, are also unique in this play as extremely ordinary. In this play, the priest's ordinary, extremely endearing old child persona becomes unique. The passage in which he squabbles with Yossi over whether to write a biography of him is a mixture of intellectual stubbornness and the firework of a grandfather-next-door kid, easily uncharacterised to capture the audience's attention with his distinctive character. This is why the conveyor belt of life on the stage turns out so many characters that the audience is so impressed and interested in each one. And we know that, like a conveyor belt that never stops, these energetic little people go on and on, delivering victory and hope for survival -- that's the ultimate comfort of war, right?

The creator breaks the routine with novel ideas, observes the characters with equal eyes, and creates the texture of life with full details-- as if he is on the scene rather than watching the fire from the other side. They are not strangers in distress but people who have lived through their ups and downs, loved and lost love just like we do.

\section{Conclusion}

As a result, when watching the drama, romantic and fresh life breath rushed to the face. After going out of the theater, sadness rose from the bottom of my heart. Which is easier to arrive, yesterday or tomorrow? There may never be an answer, but ordinary and precious days go on.

\section{References}

[1] Ru Xin, Yang Yu. Hegel's Tragedy Theory[J]. Philosophical Research,1962, 5:52

[2] Hegel. Aesthetics (Volume 3) [M]. Translated by Zhu Guangqian. Shanghai: The Commercial Press, 1981:286. 